\title{
Chemical Studies of Tissue Polypeptide Antigen (TPA). II.* Partial Amino Acid Sequences of Cyanogen Bromide Fragments of TPA Subunit $B_{1}$
}

\author{
P. REDELIUS, ${ }^{a}$ B. LÜNING ${ }^{b}$ and B. BJÖRKLUND ${ }^{a}$
}

a Section of Cancer Immunology, National Bacteriological Laboratory, S-105 21 Stockholm, Sweden and

b Institute of Organic Chemistry, Stockholm University, S-106 91 Stockholm, Sweden**

\begin{abstract}
A subunit (designated $B_{1}$ ) of the tumor associated peptide "Tissue Polypeptide Antigen" (TPA) has been cleaved by cyanogen bromide. Some of the fragments contained TPA-activity (as measured by a standardized hemagglutination inhibition method). The fragments have been separated, and partial amino acid sequences have been determined for some of the fragments. A method for purification of the most active fragment (designated $\mathrm{BrCN}: \mathrm{C}$ ) has been worked out from cleavage products obtained by cleavage with cyanogen bromide of "Washed Tissue Powder". By this method fragment BrCN:C has been isolated from a pool of placentae and a pool of carcinoma tumors, and the amino acid sequences of more than 50 amino acids from the $N$-terminus have been determined. Fragment $\mathrm{BrCN}$ : $\mathrm{C}$ has been demonstrated from three different sources, which indicates the presence of a common part in subunit $B_{1}$ independent of source.
\end{abstract}

Tissue Polypeptide Antigen (TPA) is produced and released by cancer cells in general, as has been described. ${ }^{1-6}$ It has been purified, ${ }^{6,7}$ and assay procedures have been worked out ${ }^{6}$ and used in a series of clinical studies. ${ }^{6,8-10}$

The studies on the primary structure have been performed on subunit $B_{1}$ of TPA with an apparent molecular weight of 43000 . The isolation of this subunit has been described. ${ }^{11}$

Subunit $B_{1}$ is usually prepared from pooled tumor material but, to ensure highest possible chemical

\footnotetext{
* For Part I in this series see Ref. 11.

** Present address: AB Sangtec Medical, Box 20045, S-161 20 Bromma, Sweden, to whom correspondence should be addressed.
}

homogeneity of the protein, liver metastases obtained at the autopsy of a case of primary bronchial carcinoma were used as starting material for the initial investigation.

Cleavage of subunit $B_{1}$ with cyanogen bromide resulted in a peptide mixture containing $15 \%$ of the original TPA-activity. All peptides were distributed in the gel when filtered through Sephadex G 75, while subunit $B_{1}$, because of aggregation, was excluded from the gel. This indicates cleavage under formation of active and inactive fragments (Fig. 1). The peptide fractions were further purified by rechromatography in the same column and then sequenced by the aid of an automatic spinning cup sequencer.

The PTH-derivatives* of the neutral amino acids were identified by GLC and all PTH-amino acids were hydrolyzed with hydroiodic acid to the corresponding amino acids which were identified with the aid of an automatic amino acid analyser. Using this technique, an interfering background was caused by amino acids from washed out peptide. The amino acids were, therefore, identified by plotting the mol- $\%$ composition of the amino acids in each step and observing the variation between the steps.

Amino terminal sequences were found for fragment $\mathrm{BrCN}: \mathrm{A}, \mathrm{BrCN}: \mathrm{B}$ and $\mathrm{BrCN}: \mathrm{C}$ (Fig. 5). The sequence of fragment $\mathrm{BrCN}$ :A showed great simi-

* Abbreviations used: PTH, 3-phenyl-2-thiohydantoin; SDS, sodium dodecyl sulfate; TFA, trifluoroacetic acid; PITC, phenylisothiocyanate; HFBA, heptafluorobutyric acid; HPLC, high performance liquid chromatography. 


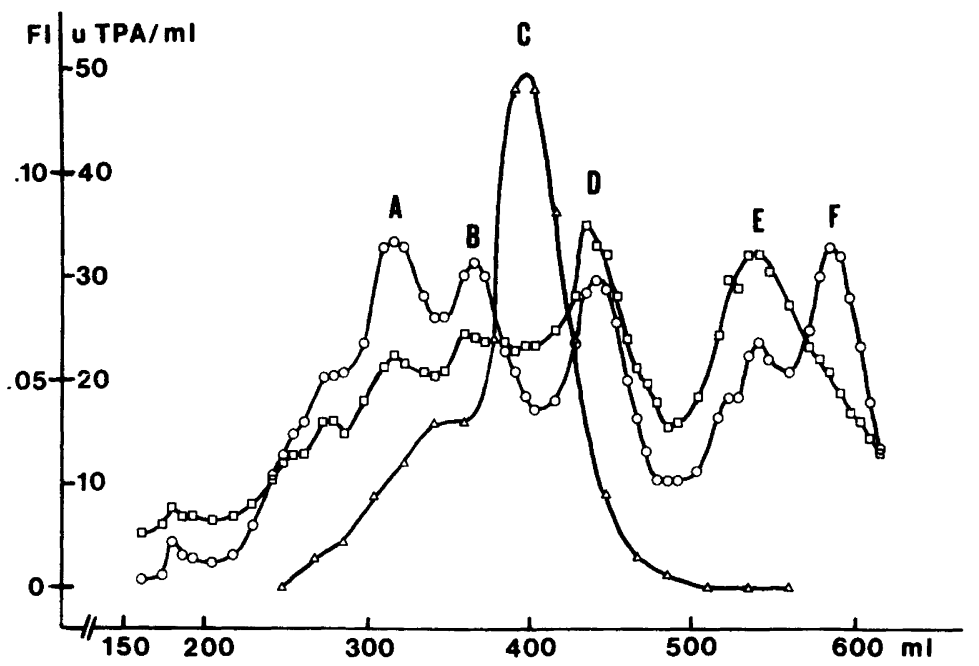

Fig. 1. Separation of peptides from cyanogen bromide cleavage of $0.6 \mathrm{mg}$ subunit $\mathbf{B}_{1}$ on a Sephadex $\mathrm{G} 75$ column $2.5 \times 135 \mathrm{~cm}$ in $0.1 \mathrm{M}$ formic acid, at a flow rate of $22 \mathrm{ml} \mathrm{h}^{-1}$ at a temperature of $6{ }^{\circ} \mathrm{C}$. Fluorescence, activation $283 \mathrm{~nm}$, emission $312 \mathrm{~nm}(\square)$, emission $350 \mathrm{~nm}(O)$, TPA-activity $(\triangle)$.

larity to that of $\mathrm{BrCN}: \mathrm{B}$. This could be explained in terms of $\mathrm{BrCN}: \mathrm{A}$ being a compound fragment containing $\mathrm{BrCN}: \mathrm{B}$ as the $N$-terminal peptide, or $\mathrm{BrCN}: \mathrm{A}$ arising because of microheterogeneity in the subunit $B_{1}$ preparation. The peptide fractions denoted $\mathrm{BrCN}: \mathrm{D}, \mathrm{BrCN}: \mathrm{E}$ and $\mathrm{BrCN}: \mathrm{F}$ contained more than one peptide. Fragment $\mathrm{BrCN}: \mathrm{C}$, which gave rise to the main active peak in Fig. 1, is adsorbed to Sephadex G 75 in $0.1 \mathrm{M}$ formic acid, resulting in a low yield of this fragment.

Cleavage of subunit $B_{1}$ originating from a pool of carcinoma tumors was also performed. After $\mathrm{BrCN}$ cleavage, the peptide mixture was filtered through the Sephadex G 75 column. The elution pattern from the column was essentially the same as for the cyanogen bromide fragments obtained from the individual tumor (Fig. 1); however, more excluded material was observed.

Further purification of the fragments was achieved with an ion exchange column (SE Sephadex C 25), eluted with a combined $\mathrm{pH}$ and ionic strength gradient. Examples of typical separations of fractions $\mathrm{BrCN}: \mathrm{C}, \mathrm{BrCN}: \mathrm{D}$ and $\mathrm{BrCN}: \mathrm{E}$ are presented in Fig. 2. Activity pertaining to fragment $\mathrm{BrCN}: \mathrm{C}$ appears as a distinct peak (Fig. 2a), however, overlapping with inactive peptide material. The resolution of pool $\mathrm{BrCN}$ : $\mathrm{E}$ was poor (Fig. 2b). Two fractions, $\mathrm{BrCN}: \mathrm{E}_{1}$ and $\mathrm{BrCN}: \mathrm{E}_{3}$, were collected for purity test and the poorly resolved peaks, denoted
$\operatorname{BrCN}: \mathrm{E}_{2}$, were collected but not further separated. Fragment BrCN:A and $\mathrm{BrCN}: \mathrm{B}$ were irreversibly adsorbed to the column in this system.

To avoid adsorption to the Sephadex G 50 column during desalting, a buffer consisting of $0.5 \mathrm{M}$ ammonium formate in $0.5 \mathrm{M}$ formic acid was used. A further purification of $\mathrm{BrCN}: \mathrm{C}$ from contaminating $\mathrm{BrCN}: \mathrm{D}_{2}$ was also achieved (Fig. 3). The eluted peptide was lyophilized.

Sequencing was performed with the automatic sequencer using an HPLC system for identification of the PTH-amino acids. The latter method permits detection of PTH-Asn and PTH-Gln as well as an elimination product from PTH-Ser (5-methylene-3phenyl-2-thiohydantoin, $R_{\mathrm{t}} \neq R_{\mathrm{t}}$ PTH-Ser), which was identified by mass spectrometry $\left(m / e: \mathrm{M}^{+} 204\right.$, $135,119,91,77)$.

Determination of the $N$-terminal amino acid sequence was performed on intact subunit $B_{1}$ and on the $\mathrm{BrCN}$ fragments $\mathrm{BrCN}: \mathrm{B}, \mathrm{BrCN}: \mathrm{C}$, $\operatorname{BrCN}: \mathrm{D}_{1}, \operatorname{BrCN}: \mathrm{D}_{2}, \operatorname{BrCN}: \mathrm{E}_{1}$ and $\mathrm{BrCN}: \mathrm{E}_{3}$ (Table 1).

Sequencing of $50 \mathrm{nmol}$ intact subunit $\mathbf{B}_{1}$ resulted in chromatograms which exhibited a background of PTH-amino acids, less than $5 \mathrm{nmol}$ in total. No sequence could be observed. Therefore, it seems reasonable to assume that the $N$-terminus of subunit $B_{1}$ is blocked. The lack of a sequence agrees with the results on a previously attempted $N$-terminal 
a

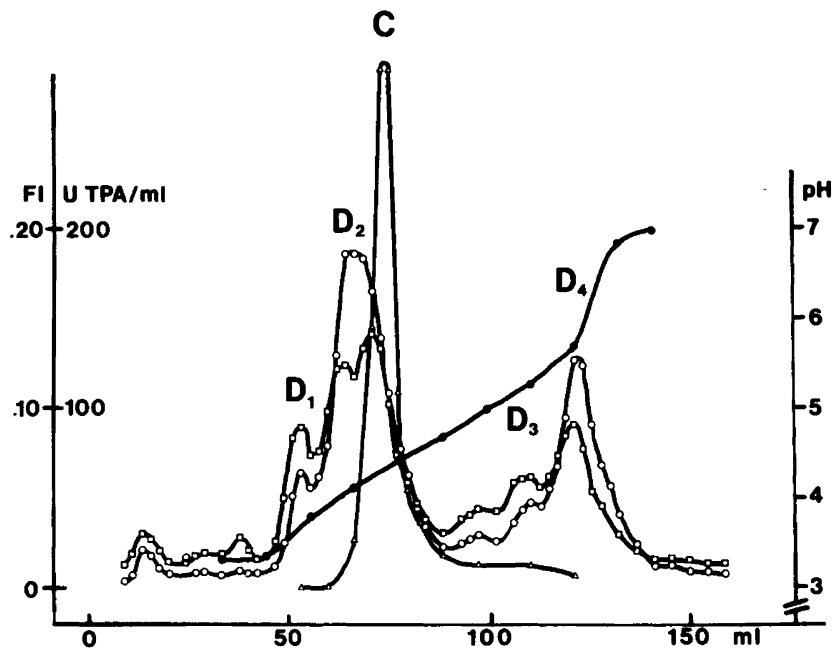

b

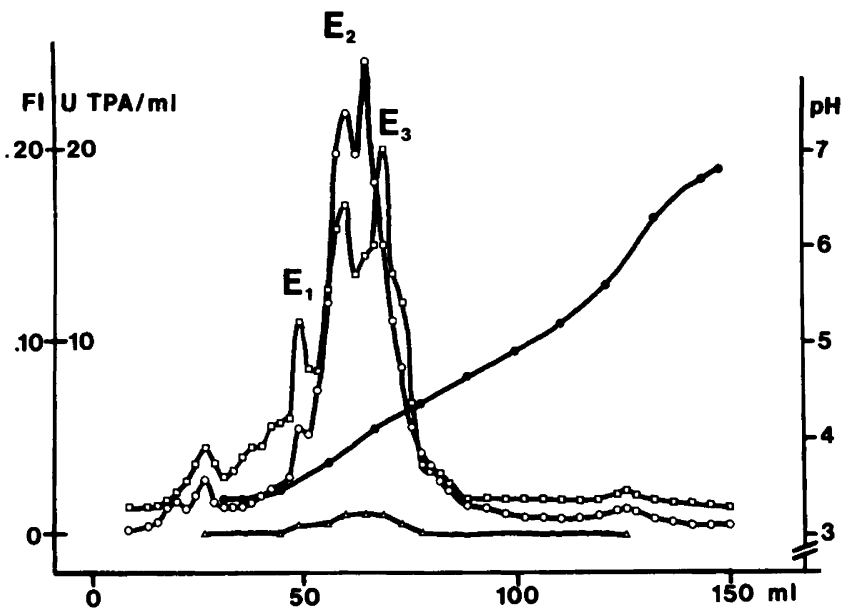

Fig. 2. Separation of fraction (a) C $-D$, (b) E from Sephadex $G 75$ filtration of cyanogen bromide fragments of subunit $B_{1}$ (see Fig. 1) on an ion exchange column SE Sephadex C $251 \times 26 \mathrm{~cm}$, eluted with a linear gradient from $67 \mathrm{mM}$ citrate $\mathrm{pH} 3.3$ to $67 \mathrm{mM}$ citrate, $0.9 \mathrm{M} \mathrm{NaCl}, \mathrm{pH} \mathrm{7.4,} \mathrm{over} 16 \mathrm{~h}$ at a flow rate of $8.1 \mathrm{ml} \mathrm{h}^{-1}$ at a temperature of $4{ }^{\circ} \mathrm{C}$. Fluorescence, activation $283 \mathrm{~nm}$, emission $312 \mathrm{~nm}(\square)$, emission $350 \mathrm{~nm}$ (O), TPA-activity $(\triangle), \mathrm{pH}(\bullet)$.

determination of subunit $B_{1}$ by the dansyl chloride method, which did not result in the finding of any $N$-terminal amino acid. ${ }^{12}$ The presence of a blocked terminus was further indicated by a sequencing experiment on fragment $\mathrm{BrCN}: \mathrm{D}_{2}$, which probably constitutes the $N$-terminal peptide of subunit $\mathbf{B}_{1}$. Here, the background of PTH-amino acids without any main sequence was less than $8 \mathrm{nmol}$ from 150 nmol of peptide.

Even though fragment $\mathrm{BrCN}: \mathrm{B}$ derived from the pool of tumors was not pure enough for an accurate and satisfactory sequencing, its identity with the corresponding fragment from the individual tumor could be excluded. On the other hand, it could be demonstrated that the sequence of fragment $\mathrm{BrCN}$ :C was identical in both cases of origin (Fig. 


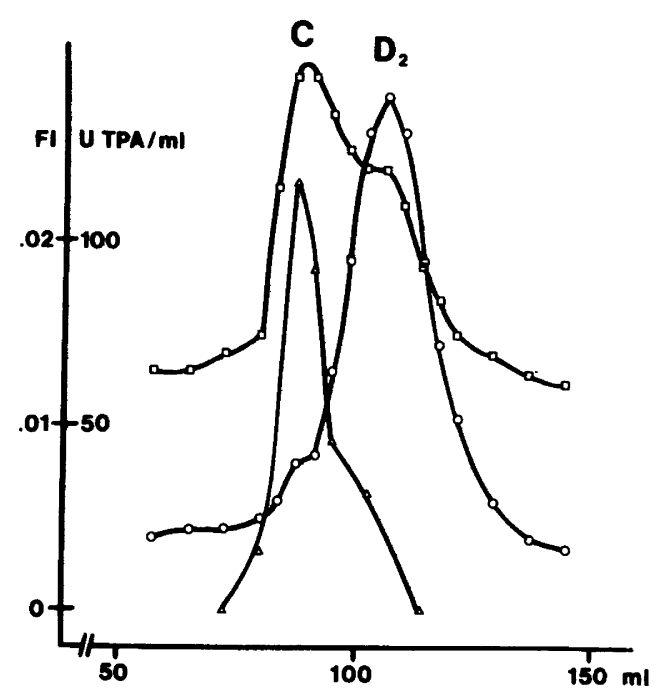

Fig. 3. Separation and desalting of fragment $\mathrm{BrCN}$ :C (eluted from the ion exchange column) in a Sephadex G 50 fine column $2 \times 53 \mathrm{~cm}$ eluted with $0.5 \mathrm{M}$ ammonium formate in $0.5 \mathrm{M}$ formic acid, at a flow rate of $33 \mathrm{ml} \mathrm{h}^{-1}$ and at a temperature of $22{ }^{\circ} \mathrm{C}$. Fluorescence, activation $283 \mathrm{~nm}$, emission $312 \mathrm{~nm}(\square)$, emission $350 \mathrm{~nm}(\mathrm{O})$, TPA-activity $(\triangle)$

5). During the analysis the rest peptide became soluble in 1-chlorobutane around step 30 and was washed out from the reaction cup.

The fractions BrCN:D ${ }_{1}$ and $\mathrm{BrCN}: \mathrm{E}_{3}$ were not pure enough to permit the detection of a sequence.

To facilitate the further analysis of fragment $\mathrm{BrCN}: \mathrm{C}$, an alternative method of isolation was developed which resulted in $100 \times$ higher yield.

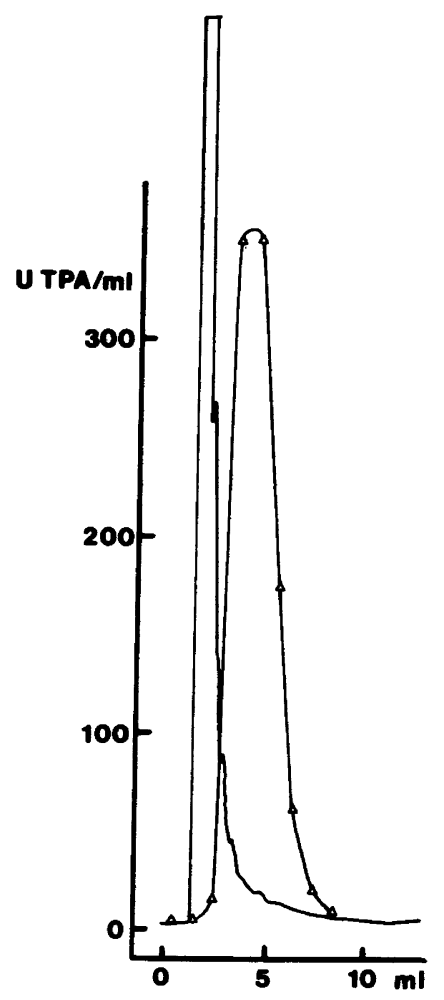

Fig. 4. Chromatography of $0.5 \mathrm{mg}$ TPA-active fractions, eluted from the ion exchange column, with a $\mu$-Bondapak $\mathrm{C}_{18}$ column $3.8 \times 300 \mathrm{~mm}$, eluted with a buffer consisting of $0.1 \mathrm{M}$ ammonium formate in $80 \%$ methanol. Flow rate $2 \mathrm{ml} \mathrm{min}^{-1}$. Absorbance at $254 \mathrm{~nm}$, solid line; TPA-activity $(\triangle)$.

Table 1. Fragments from $\mathrm{BrCN}$ cleavage of TPA subunit $\mathrm{B}_{1}$ from pooled tumors.

\begin{tabular}{|c|c|c|c|c|c|}
\hline Fragment & $\begin{array}{l}\text { Molecular } \\
\text { weight }\end{array}$ & $\begin{array}{l}\text { Specific } \\
\text { activity/ } \\
U \mu \mathrm{g}^{-1}\end{array}$ & $\begin{array}{l}\text { Activity cal- } \\
\text { culated from } \\
\text { subunit } \mathrm{B}_{1} / \%\end{array}$ & $\begin{array}{l}\text { Amount/ } \\
\mathrm{mg}\end{array}$ & Remarks \\
\hline $\mathrm{BrCN}: \mathrm{B}$ & 14000 & 1.0 & 5 & 2.24 & Not pure \\
\hline $\mathrm{BrCN}: \mathrm{C}$ & 9000 & 2.1 & 10 & 0.68 & Thirty steps sequenced \\
\hline $\mathrm{BrCN}: \mathrm{D}_{1}$ & 7000 & 0 & & 0.46 & Not pure \\
\hline $\mathrm{BrCN}: \mathrm{D}_{2}$ & 7000 & 0.4 & 1 & 0.83 & Blocked \\
\hline $\mathrm{BrCN}: \mathrm{D}_{3}$ & 7000 & 0.2 & 0.5 & 0.11 & Not sequenced \\
\hline $\mathrm{BrCN}: \mathrm{D}_{4}$ & 7000 & 0.4 & 1 & 0.07 & Not sequenced \\
\hline $\mathrm{BrCN}: \mathrm{E}_{1}^{4}$ & 3000 & 0 & & 0.28 & Seventeen steps sequenced \\
\hline $\mathrm{BrCN}: \mathrm{E}_{2}$ & 3000 & 0.01 & 0.01 & 0.92 & Not sequenced \\
\hline $\mathrm{BrCN}: \mathrm{E}_{3}$ & 3000 & 0 & & 0.64 & Not pure \\
\hline
\end{tabular}


Cleavage with cyanogen bromide was performed on a crude material (WTP, Washed Tissue Pow$\operatorname{der}^{5,6}$ ) originating froma pool of carcinoma tumors and from a pool of human placentae, both tissues of which were known to contain the same type of antigenicity. ${ }^{6}$ Peptides obtained by $\mathrm{BrCN}$ cleavage of WTP originating from the two sources were treated separately throughout the purification procedures.

Each lyophilized peptide mixture was dissolved in $0.1 \mathrm{M}$ formic acid and the solution was frozen, thawed and centrifuged. The clear supernatant was filtered through Sephadex G 75 and the fraction containing TPA-activity was further purified by ion exchange chromatography on SP Sephadex C 25, essentially as described above. The peptide fraction from the ion exchange column was desalted by means of a SEP-PAK $\mathrm{C}_{18}$ cartridge, in which the peptide was adsorbed. After elution of the peptide, final purification was achieved with HPLC (Fig. 4).

Sequencing was performed with a program employing 1.0 M Quadrol*-TFA buffer and double cleavage with HFBA as described above. To minimize the risk for wash out of the peptide from the reaction cup, polybrene ${ }^{13}$ was used as a carrier and the program was changed after $20-40$ steps.

* $N, N, N^{\prime}, N^{\prime}$-Tetra(2-hydroxypropyl)-1,2-diaminoethane.
The change included the use of $0.2 \mathrm{M}$ QuadrolTFA buffer, washing with less ethyl acetate and single cleavage with HFBA. A limiting factor in the use of this program is incomplete cleavage of the phenylthiocarbamyl peptide, resulting in an increased trailing of the PTH-amino acids in subsequent steps.

Sequencing of $1.1 \mathrm{mg}$ of the fragment $\mathrm{BrCN}: \mathrm{C}$ originating from pooled placentae indicated that the preparation was pure $(>95 \%)$. The sequence could be followed for 56 amino acids from the $\mathrm{N}$-terminal. In steps 37 and 42 about $50 \%$ PTH-Arg and $50 \%$ PTH-Lys were observed, possibly due to microheterogeneity in the preparation. No amino acid could be identified after $\mathrm{Asp}_{56}$ (Fig. 5).

Sequencing of $2.8 \mathrm{mg}$ fragment $\mathrm{BrCN}: \mathrm{C}$ originating from pooled tumors showed that this preparation contained approximately $40 \%$ of contaminating peptides, the major one being a cyanogen bromide fragment from actin. This fragment was identified by comparison with the known sequence ${ }^{14}$ of a $\mathrm{BrCN}$ fragment from amino acid 83 to 119 in muscle actin from rabbit. By subtraction of the contribution to the HPLC chromatograms of this peptide, 53 amino acids in 56 positions in fragment $\mathrm{BrCN}: \mathrm{C}$ could be identified (Fig. 5).

These results show identity of considerable parts of subunit $\mathrm{B}_{1}$ fragment $\mathrm{BrCN}: \mathrm{C}$, obtained from pooled human carcinoma tissues with those of the

Table 2. Amino acid composition (mol- $\%$ ) of TPA subunit $\mathrm{B}_{1}$ and $\mathrm{BrCN}$ fragments from subunit $\mathrm{B}_{1}$.

\begin{tabular}{lccccc}
\hline & Subunit $\mathrm{B}_{1}$ & $\begin{array}{l}\text { Single tumor } \\
\text { BrCN:A }\end{array}$ & BrCN:B & \multicolumn{2}{c}{ Pooled tumors } \\
& & 11.8 & 12.6 & 10.1 & 11.6 \\
\hline Asp & 11.2 & 5.1 & 5.3 & 1.1 & 3.5 \\
Thr & 5.1 & 7.1 & 6.7 & 4.7 & 9.4 \\
Ser & 7.2 & 18.4 & 18.0 & 23.1 & 16.6 \\
Glu & 17.9 & 2 & 2 & $<2$ & $<2$ \\
Pro & 2 & 5.4 & 5.4 & 5.3 & 4.2 \\
Gly & 5.8 & 9.3 & 9.3 & 17.8 & 12.1 \\
Ala & 8.6 & $<0.5$ & $<0.5$ & $<0.5$ & $<0.5$ \\
Cys & $<0.2$ & 4.8 & 4.8 & 1.1 & 4.7 \\
Val & 6.1 & $<0.5$ & $<.5$ & $<0.5$ & $<0.5$ \\
Met & 1.8 & 3.3 & 5.0 & 7.6 & 9.9 \\
Ile & 5.4 & 8.0 & 10.0 & 13.1 & 6.2 \\
Leu & 10.8 & 2.8 & 2.4 & $<0.5$ & 2.4 \\
Tyr & 2.5 & 2.5 & 1.7 & $<0.5$ & 0.5 \\
Phe & 2.5 & 0.9 & 1.0 & 0.3 & 0.6 \\
His & 1.6 & 6.9 & 8.2 & 7.2 & 13.0 \\
Lys & 6.8 & 6.9 & 7.8 & 8.6 & 5.7 \\
Arg & 6.7 & & & & \\
\hline
\end{tabular}

Acta Chem. Scand. B 34 (1980) No. 4 
15

10

15

20

25

BrCN:A

single tumor

A V L B B R L A - Y L B $\underset{G}{Z} \operatorname{VR} \underset{R}{\mathrm{Z}} \ldots$

BrCN:B

single tumor

A V L NDR L A QY L DE VR A L E A A NG - L E V L ......

$\mathrm{BrCN}: \mathrm{C}$

single tumor

B R B I - R L Z A Z ......

$\mathrm{BrCN}: \mathrm{C}$

pooled tumors

NR NI S RLQAEI EGLKGQRASLEAAI ADAEQ

BrCN:C

pooled placentae

NR NI S RL QAEI EGLKGQRAS LEAAI A DAEQ

$\mathrm{BrCN}: \mathrm{E}_{1}$ pooled tumors

D-I I A E VKA QYE D-A - R .....

35

40

45

50

55

$\mathrm{BrCN}: \mathrm{C}$

pooled tumors

R GE L A I K DA NAKL S - - -A A L QR AKQD.....

BrCN:C

pooled placentae

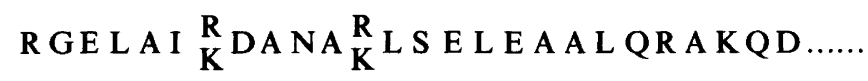

Fig. 5. Partial amino acid sequences of $\mathrm{BrCN}$-fragments from TPA subunit $\mathbf{B}_{1}$.

corresponding fragment from pooled human placentae. Considering the $N$-terminal sequence of $\mathrm{BrCN}: \mathrm{C}$ from an individual human carcinoma tumor, the amino acid sequences demonstrate, that subunit $B_{1}$ from one tumor, a mixture of tumors and a mixture of placentae, respectively, contain a peptide fragment in common.

The sequences reported for fragments of subunit $B_{1}$ do not show any significant similarities with any sequences previously published. ${ }^{14}$ Preliminary syn-

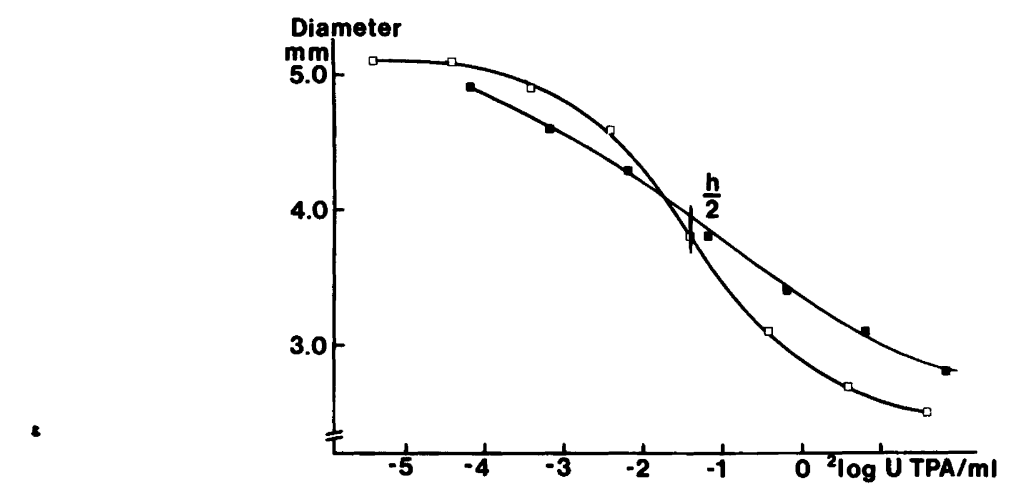

Fig. 6. Comparison of the agglutination pattern for a standard $(\square)$ and fragment $\operatorname{BrCN}: \mathrm{C}(\square)$. Maximum diameter is $5.1 \mathrm{~mm}$, and minimum diameter is $2.5 \mathrm{~mm}$ for the standard and $2.8 \mathrm{~mm}$ for fragment $\mathrm{BrCN}$ :C. The points of the half height (marked with a vertical line) are placed over each other by displacement of the curve for fragment $\mathrm{BrCN}: \mathrm{C}$, and these points are said to correspond to the same concentration of activity. 
thesis work based on fragments from subunit $\mathbf{B}_{1}$ have resulted in specifically active as well as inactive peptides.

\section{EXPERIMENTAL}

Chemicals used in the sequencer were "Sequenal grade" (Pierce), acetonitrile used for HPLC was "Spectro grade" with absorbance $<0.005$ at 254 $\mathrm{nm}$; all other chemicals were "Analytical grade". All percentages are $\mathrm{v} / \mathrm{v}$.

Fluorescence intensity $(\mathrm{FI})$ was measured with the aid of an Aminco-Bowman spectrofluorometer, model 4-8106.

Determination of TP A antigenic activity. The TPAactivity was measured by a standardized hemagglutination inhibition assay ${ }^{6,10}$ and the activity was quantitated by comparing the sample with a standard. The standard was empirically determined as defined in Ref. 10. The comparison was performed by plotting the agglutination diameters versus ${ }^{2} \log$ [TPA] in a diagram for the sample and a standard (Fig. 6). Since the curves for subunit $\mathbf{B}_{1}$ and its cleavage products were not identical with respect to slope and minimum diameters, it was decided to use the $50 \%$ diameters of the agglutination pattern as representing comparable activity of TPA in a strictly standardized system using known solutions of TPA for reference.

Starting material. Subunit $\mathrm{B}_{1}$ was purified, as has been described, ${ }^{11}$ from liver metastases obtained at the autopsy of a patient who died from cancer originating as a primary bronchial carcinoma. Subunit $B_{1}$ was also purified from a pool of 63 tumors, ${ }^{*}$ by the same method.

"Washed Tissue Powder" (WTP) was prepared, as has been described, ${ }^{6}$ from a pool of 9 carcinoma tumors.** WTP was also prepared from a pool of 27 placentae which were obtained immediately after delivery and stored on ice. Within $24 \mathrm{~h}$ the placentae were washed with saline to remove as much blood as possible, cut into $2 \mathrm{~cm}$ cubes and frozen at $-24{ }^{\circ} \mathrm{C}$. The frozen material was then processed in the same way as frozen tumors. ${ }^{11}$

$B r C N$ cleavage. Lyophilized subunit $\mathbf{B}_{1}(0.6 \mathrm{mg})$ was dissolved in $2 \mathrm{ml} 70 \%$ aqueous formic acid whereupon $18 \mathrm{mg}$ crystalline cyanogen bromide

\footnotetext{
* Diagnoses of deceased patients from which tumor tissues were obtained: 12 Pulmonary cancer; 3 rectal ca.; 4 colonic ca.; 6 mammary ca.; 3 gastric ca.; 4 pancreatic ca.; 3 gall bladder ca.; 1 caecum ca.; 2 uterus ca.; 1 ovarian ca.; 3 bronchial ca.; 1 oesophageal ca.; 2 duodenal ca.; 1 renal ca.; 1 hepar ca.; 1 laryngeal ca.; 1 prostate ca.; 1 cerebellar ca.; 1 hypernephroma; 2 leukaemia; 1 Hodgkin's disease; 1 malignant lymphoma; 1 fibromyxosarcoma; 7 unknown.

** 7 Colonic cancer; 1 pulmonary ca.; 1 gall bladder ca.
}

was added. The reaction was allowed to proceed for $24 \mathrm{~h}$ at $22{ }^{\circ} \mathrm{C}$ and then the reaction mixture was diluted 20 times with water, shell-frozen, and lyophilized, essentially as has been described. ${ }^{15}$

For cleaving WTP a modified procedure was used. $1 \mathrm{~g}$ lyophilized WTP was soaked with small portions of anhydrous formic acid under intense mincing with a glass rod, until a total of $18 \mathrm{ml}$ formic acid had been added. The jelly that formed was diluted with $7.5 \mathrm{ml}$ water, $1 \mathrm{~g}$ crystalline cyanogen bromide was added and the mixture was treated as above.

Peptide separations. The lyophilized peptide mixture resulting after $\mathrm{BrCN}$ cleavage of subunit $\mathrm{B}_{1}$ was dissolved in $0.1 \mathrm{M}$ formic acid and separated on a $135 \mathrm{~cm}$ Sephadex G 75 column eluted with the same solution (Fig. 1). Further purification of the fragments was achieved by ion exchange chromatography in a column with SE Sephadex C 25, which was eluted with a combined ion strength and $\mathrm{pH}$ gradient maintained with a buffer containing $67 \mathrm{mM}$ citrate and $\mathrm{NaCl}$ (for details see Fig. 2). Fractions from the ion exchange column were designated by an index. After concentration in a Büchi rotating evaporator, the fractions were filtered through Sephadex G 50 coarse, eluted with $0.5 \mathrm{M}$ ammonium formate in $0.5 \mathrm{M}$ formic acid. The purity of the fragments was tested by sequencing.

The lyophilized peptide mixture resulting from BrCN cleavage of WTP was dissolved in $0.1 \mathrm{M}$ formic acid, frozen, thawed and centrifuged at $1500 \mathrm{~g}$ for $30 \mathrm{~min}$. The clear supernatant, containing the active fragments was subjected to gel filtration followed by ion exchange chromatography of the active peak as above. The active peptide fraction $(100 \mathrm{ml})$ from the ion exchange column was passed through a SEP-PAK $C_{18}$ cartridge (Waters) in which the active peptide was adsorbed. The peptide was desorbed with $3 \mathrm{ml}$ buffer, made up of $0.1 \mathrm{M}$ ammonium formate in $90 \%$ methanol, pressed through the cartridge by means of a syringe. The solution containing the active peptide was concentrated by evaporation in a Büchi rotating evaporator.

Final purification was achieved by HPLC as shown in Fig. 4. The column permitted a repeated charge of $1 \mathrm{mg}$ peptide mixture at each run. The yield of the pure fragment $\mathrm{BrCN}: \mathrm{C}$ was $0.2 \mathrm{mg}$ from $1 \mathrm{~g}$ WTP made up from tumors, and $0.6 \mathrm{mg}$ from $1 \mathrm{~g}$ WTP from placentae.

Amino acid analysis. $\mathrm{HCl}$ hydrolysates were analyzed with the aid of an automatic amino acid analyzer (Jeol JLC-6AH) using a $30 \mathrm{~cm}$ column of Durrum DC-6A and the Durrum Pico Buffer System II (both from Pierce, Rockford, Ill). The buffers were supplied to the column through an ammonia filtration system. Results of amino acid analyses are presented in Table 2. Amino acid analyses were 
also used to determine the total amount of peptide (Table 1).

Sequencing was performed with a Jeol JAS 47K spinning cup sequencer. The lyophilized peptide sample was dissolved in $2.5 \mathrm{ml} 0.1 \mathrm{M}$ formic acid and transferred to the reaction cup of the sequencer, where it was dried in a stream of $\mathrm{N}_{2}$ and finally under a vacuum. The sequencing was performed by means of a standard program. ${ }^{16}$ All reactions were carried out at $50{ }^{\circ} \mathrm{C}$. The peptide was coupled to PITC, by the addition of $0.4 \mathrm{ml}$ of a $5 \%$ solution of PITC in heptane, mixed with $1.3 \mathrm{ml}$ 1.0 M Quadrol-TFA buffer $\mathrm{pH}$ 9.5. The reaction mixture was washed with $16 \mathrm{ml}$ benzene followed by $21 \mathrm{ml}$ ethyl acetate. Cleavage was performed with $1.3 \mathrm{ml} \mathrm{HFBA}$, which was removed under a vacuum. The thiazolinone derivatives formed were extracted and transferred to a fraction collector with $12 \mathrm{ml}$ 1-chlorobutane. The cleavage step was repeated in each cycle.

To reach higher repetitive yield the technique for sequencing was improved by using polybrene* as a carrier for the peptides in the reaction cup. ${ }^{13}$ To diminish wash out of peptide a new program was used that utilized $0.2 \mathrm{M}$ Quadrol-TFA buffer, which permitted washing with $10 \mathrm{ml}$ ethyl acetate, and that performed single cleavage with HFBA and single extraction with 1-chlorobutane. The standard program permitted a repetitive yield of $96 \%$ to be obtained, and the program using single cleavage permitted a repetitive yield of $95 \%$.

Identification of the amino acids. The 1-chlorobutane solutions of thiazolinone derivatives of the amino acids were evaporated to dryness in a stream of $\mathrm{N}_{2}$ and converted to the corresponding PTHderivatives by heating to $80^{\circ} \mathrm{C}$ for $10 \mathrm{~min}$ in $1 \mathrm{ml}$ $1 \mathrm{M} \mathrm{HCl}$. The samples were extracted with $3 \times 1 \mathrm{ml}$ ethyl acetate. The ethyl acetate was evaporated to dryness in a stream of $\mathrm{N}_{2}$ and the residue was dissolved in $50 \mu \mathrm{l}$ ethyl acetate. The PTH-derivatives of the neutral amino acids were identified by GLC on a Jeol gas chromatograph JGC 20K equipped with a $190 \mathrm{~cm}$ SP 400 column, used with a temperature rise of $6^{\circ} \mathrm{C} / \mathrm{min}\left(R_{\mathrm{t}}\right.$ PTH-Ala 8.1, PTH-Gly 9.0, PTH-Val 9.6, PTH-Leu/PTH-Ile 11.2, PTH-Phe $18.5 \mathrm{~min}$ ). All PTH-amino acids were hydrolyzed with $1 \mathrm{ml}$ hydroiodic acid at $140{ }^{\circ} \mathrm{C}$ for $18 \mathrm{~h}$ in evaluated ampoules, to the corresponding amino acids. ${ }^{17}$ Hydroiodic acid was removed with $\mathrm{N}_{2}$ at elevated temperature $\left(50{ }^{\circ} \mathrm{C}\right)$. The amino acids were then identified by the aid of the automatic amino acid analyzer.

When using HPLC for identification of the PTHamino acids, the ethyl acetate extraction becomes

\footnotetext{
* 1,5-Dimethyl-1,5-diazaundecamethylene-polymethobromide.
}

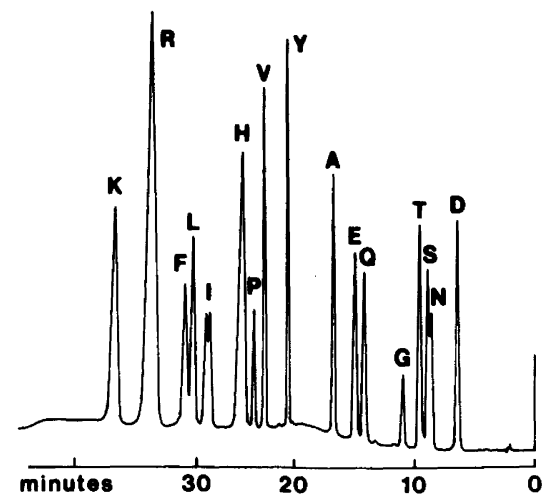

Fig. 7. Chromatogram showing the separation of 17 PTH-amino acids with a $3.8 \times 300 \mathrm{~mm}$ Spherisorb S5 ODS column eluted with a concave acetonitrile gradient. The standard contains $2.5 \mathrm{nmol}$ of each PTH-amino acid except PTH-Arg and PTH-His of which the standard contains $10 \mathrm{nmol}$. The absorbance was measured at $254 \mathrm{~nm}$ at a sensitivity of 0.1 .

unneccessary. The $\mathrm{HCl}$ solutions containing the PTH-amino acids were instead evaporated to dryness in a Büchi rotating evaporator, redissolved in $50 \mu \mathrm{l}$ methanol, and identified by HPLC.

HPLC of PTH-amino acids. The HPLC system (Waters) consisted of two pumps (model 6000A), a solvent programmer (model 660) and an absorbance detector (model 440). A $3.8 \times 300 \mathrm{~mm}$ reverse phase column (Spherisorb S5 ODS, 7700 plates) was employed and eluted with a concave gradient (No. 8) from 6 to $29 \%$ of acetonitrile in $35 \mathrm{mM}$ acetate buffer $\mathrm{pH} 4.07$ for $15 \mathrm{~min}$, followed by $29 \%$ acetonitrile in the acetate buffer isocratically for 20 min. The flow rate was $1.5 \mathrm{ml} \mathrm{min}-1$. With this program resolution of $17 \mathrm{PTH}$-amino acids was obtained (Fig. 7).

With elution times for PTH-Glu and PTH-Asp being extremely sensitive to changes in $\mathrm{pH}$ and elution times for PTH-Arg and PTH-His being sensitive to changes of ionic strength, maximal resolution was achieved only by fine-tuned adjustment of $\mathrm{pH}$ and ionic strength.

\section{REFERENCES}

1. Björklund, B. Int. Arch. Allergy Appl. Immunol. 8 (1956) 179.

2. Björklund, B. and Björklund, V. Int. Arch. Allergy Appl. Immunol. 10 (1957) 153.

3. Björklund, B., Lundblad, G. and Björklund, V. Int. Arch. Allergy Appl. Immunol. 12 (1958) 241. 
4. Björklund, B. and Paulsson, J. J. Immunol. 89 (1962) 759.

5. Björklund, B. Int. Arch. Allergy Appl. Immunol. 36 (1969) 191.

6. Björklund, B., Björklund, V., Wiklund, B., Lundström, R., Ekdahl, P. H., Hagbard, L., Kaijser, K., Eklund, G. and Lüning, B. Immunological Techniques for Detection of Cancer, Bonnier, Stockholm 1973, pp. 134-184, 237 242.

7. Björklund, B. Anal. Biochem. 41 (1971) 287.

8. Kumar, S., Wilson, P., Brenchley, P., Taylor, G., Björklund, B. and Eklund, G. Int. J. Cancer 22 (1978) 542.

9. Menendez-Botet, C., Oettgen, H., Pinsky, C. and Schwartz, M. Clin. Chem. 24 (1978) 868.

10. Björklund, B. In Schönfeld, H., Ed., Antibiotics and Chemotherapy, Karger, Basel 1978, Vol. 22, pp. 16-31.

11. Lüning, B., Wiklund, B., Redelius, P. and Björklund, B. Biochim. Biophys. Acta (1980). In press.

12. Wiklund, B., Lüning, B. and Björklund, B. Biochim. Biophys. Acta (1980). In press.

13. Klapper, D. G., Wilde, C. E., III and Capra, J. D. Anal. Biochem. 85 (1978) 126.

14. Dayhoff, M. O., Hunt, L. T., Barker, W. C., Schwartz, R. M. and Orcutt, B. C. Protein Segment Dictionary 78, National Biomedical Research Foundation, Washington, D.C. 1978, Vol. 5.

15. Steers, E., Jr., Craven, C. R., Anfinsen, C. B. and Bethune, J. L. J. Biol. Chem. 240 (1965) 2478.

16. Edman, P. and Begg, G. Eur. J. Biochem. 1 (1967) 80.

17. Inglis, A. S., Nicholls, P. W. and Roxburgh, C. M. Aust. J. Biol. Sci. 24 (1971) 1247.

Received November 5, 1979. 